\title{
Actin cortical cytoskeleton and cell wall synthesis in regenerating protoplasts of the Saccharomyces cerevisiae actin mutant DBY 1693
}

\author{
Marie Kopecká and Miroslav Gabriel
}

Department of Biology, Faculty of Medicine, Masaryk University, 66243 Brno, Jostova 10, Czech Republic

\author{
Author for correspondence: Marie Kopecká. Tel: +42542126 266. Fax: +42542126200. \\ e-mail: mkopecka@med.muni.cz
}

\begin{abstract}
The relationship between the actin cytoskeleton and cell wall synthesis was studied by light and electron microscopy in protoplasts of Saccharomyces cerevisiae DBY 1693 containing the act1-1 allele. Since protoplasting also disturbs the actin cytoskeleton, these mutant protoplasts had a double error in their actin cytoskeletons. In the period between the onset of wall synthesis and completion of the wall, protoplasts grown at the permissive temperature showed an even distribution of actin patches all over the surface on which a new cell wall was being synthesized. After wall completion, actin patches partially disappeared, but then re-appeared, accumulated in growth regions at the start of polarized growth. This was compared with the pattern of actin patches observed in intact temperature-sensitive actin mutant cells cultivated at the permissive temperature. Electron microscopy of freeze-etched replicas revealed finger-like invaginations of the plasma membrane in both the actin mutant cells and their protoplasts. These structures showed a very similar distribution to the actin patches detected by rhodamine phalloidin staining in the fluorescence microscope. A hypothesis is presented, explaining the role of actin patches/finger-like invaginations of the plasma membrane in the synthesis of $\beta$-(1 $\rightarrow 3)$-D-glucan wall microfibrils in yeast cells.
\end{abstract}

Keywords: Saccharomyces cerevisiae, actin microfilaments, wall synthesis, $\beta-(1 \rightarrow 3)$-Dglucan microfibrils, electron microscopy

\section{INTRODUCTION}

Actin mutants of yeasts, mutated in the actin gene $A C T 1$, have a weakened cytoskeleton and their phenotype differs from the wild-type cells not only at the restrictive temperature $\left(37^{\circ} \mathrm{C}\right)$, but also at the permissive temperature $\left(23^{\circ} \mathrm{C}\right)$. This makes them suitable model objects for investigating the role of the actin cytoskeleton in cell morphogenesis.

Saccharomyces cerevisiae wild-type cells (strain DBY 1690) have normal $A C T 1$ actin alleles and their actin cytoskeleton appears as actin cortical patches in the bud and around the septum, i.e. in areas of active wall synthesis. Actin is also present as actin cables, which are loose bundles along the longitudinal cell axis (Novick \& Botstein, 1985; Gabriel et al., 1992). This is similar to that

Abbreviation: ts, temperature-sensitive. shown in other wild-type strains of budding yeasts (Kilmartin \& Adams, 1984; Adams \& Pringle, 1984; Barnes et al., 1990).

The actin mutant $S$. cerevisiae DBY 1693 was constructed by Shortle et al. (1984) using recombinant DNA technology. By substitution mutation, the CCA codon at position 32 in the $A C T 1$ actin gene was changed to CTA. This point mutation caused leucine to be substituted for proline in the gene product of the mutated act1-1 allele causing a temperature-sensitive (ts), conditionally lethal phenotype (Novick \& Botstein, 1985). It is not clear whether this mutation results in impaired polymerization of G-actin into F-actin microfilaments or failure of microfilaments to assemble into bundles. Although fluorescence microscopy cannot identify single microfilaments, these are considered necessary for polar growth of yeast actin mutants at the permissive temperature (Novick \& Botstein, 1985). Actin microfilaments have been detected as loose bundles, termed cytoplasmic actin 
cables, in wild-type strains (Kilmartin \& Adams, 1984; Adams \& Pringle, 1984; Novick \& Botstein, 1985; Gabriel et al., 1992). In the DBY 1693 mutant cell with the act1-1 allele, the weakened actin cytoskeleton consists of actin patches mainly accumulated in growing buds and septa, but also present in mother cells. Even at the permissive temperature $\left(23^{\circ} \mathrm{C}\right)$, cytoplasmic actin cables are almost invisible in mutant cells (Novick \& Botstein, 1985).

Transfer of the actin mutants to a restrictive temperature $\left(37^{\circ} \mathrm{C}\right)$ permits the full manifestation of the conditionally lethal act 1-1 mutation. Consequently, the vitally important actin microfilaments cease to function and the cells die (Novick \& Botstein, 1985).

An even distribution of actin patches and complete disappearance of actin cables, which is the phenotypic expression of the ts conditionally lethal act1-1 mutation (Novick \& Botstein, 1985; Gabriel \& Kopecká, 1995), can also be induced by protoplasting in wild-type yeast cells (Gabriel et al., 1992). However, in contrast to actin mutants, protoplasts of budding yeasts with the wild-type actin allele are capable of restoring their actin cytoskeleton during the process of cell wall regeneration (Gabriel et al., 1992). Therefore, protoplasts derived from actin mutant cells have a double error in the actin cytoskeleton which, at the genotype level, is due to mutation in the actin gene and, at the phenotype level, due to protoplasting. This offered an opportunity to study the relationship between the actin cytoskeleton and synthesis of wall components.

Protoplasts of budding yeasts require solid media for regeneration of their cell walls (Nečas \& Svoboda, 1985). However, solid medium is no longer needed after the new wall has been constructed for the reversion of protoplasts with regenerated walls to budding cells (Nečas \& Svoboda, 1985). This fact made it necessary to cultivate protoplasts of actin mutant cells using a modification of the method described previously for regeneration of wildtype protoplasts (Gabriel et al., 1992).

The objective of this study was to investigate the following questions.

1. Can actin mutant cells produce protoplasts that retain their ability to regenerate cell walls and subsequently revert to budding cells?

2. Are there any differences between wild-type and mutant cells in localization of actin patches during protoplast formation, cell wall regeneration and reversion to cells?

3. Is the process of cell-wall construction different in wall regeneration of wild-type protoplasts and actin mutant cells?

4. Can the similarity of the wall synthesis in protoplasts and actin mutant cells contribute to the understanding of the role of actin patches and finger-like invaginations of the plasma membrane?

\section{METHODS}

Yeast strain. The ts conditionally lethal actin mutant of Saccharomyces cerevisiae (Novick \& Botstein, 1985) was kindly provided by Professor David Botstein and Dr P. Grisafi of the Massachusetts Institute of Technology, Cambridge, USA. The strain used was DBY 1693, genotype act1-1/act1-1, $M A T \mathrm{a} / M A T \alpha$, ura3 $-52 /+$, bis4-619/ + (Novick \& Botstein, 1985).

Media. Cells for actin cytoskeleton studies were cultivated in YEPD medium, comprising $1 \%(\mathrm{w} / \mathrm{v})$ yeast extract, $2 \%(\mathrm{w} / \mathrm{v})$ bactopeptone and $2 \%(\mathrm{w} / \mathrm{v})$ glucose (Novick \& Botstein, 1985). To prepare protoplasts, cells were grown in malt extract medium, pH 5.5 , at $23^{\circ} \mathrm{C}$. Protoplasts were regenerated in a $1: 1$ $(\mathrm{v} / \mathrm{v})$ mixture of YEPD and N1 medium $(5 \mathrm{~g}$ glucose, $1.25 \mathrm{~g}$ asparagine, $1.25 \mathrm{~g} \mathrm{KH}_{2} \mathrm{PO}_{4}, \quad 0.425 \mathrm{~g} \mathrm{MgSO}_{4} .7 \mathrm{H}_{2} \mathrm{O}, 50 \mathrm{ml}$ distilled water; Kelleti et al., 1954). Osmotic stabilization was achieved with $0.8 \mathrm{M}$ mannitol. Solid media contained $30 \%$ $(\mathrm{w} / \mathrm{v})$ gelatin dissolved in YEPD-N1 medium.

Protoplast preparation. Cells growing in malt extract medium were collected in the exponential phase, washed twice by centrifugation with distilled water and exposed to snail enzyme medium $[10 \%, \mathrm{w} / \mathrm{v}$, snail enzyme (isolated and purified crude digestive juice of Helix pomatia dried at $\left.0{ }^{\circ} \mathrm{C}\right) 0.8 \mathrm{M}$ mannitol, citrate phosphate buffer, $\mathrm{pH} 5.6,0.01 \mathrm{M} \mathrm{MgSO}_{4}$ ] for $60-$ $120 \mathrm{~min}$ at $23^{\circ} \mathrm{C}$. Protoplasts were harvested and washed twice by centrifugation at $670 \mathrm{~g}$ for $6 \mathrm{~min}$ with an osmotic stabilizer.

Protoplast regeneration. Protoplasts were allowed to regenerate cell walls in $30 \%$ (w/v) gelatin (Nečas, 1961 ; Svoboda \& Nečas, 1966) dissolved in regeneration medium osmotically stabilized with $0.8 \mathrm{M}$ mannitol. A $0.1 \mathrm{ml}$ suspension of protoplasts $\left(6 \times 10^{7} \mathrm{ml}^{-1}\right)$ in osmotic stabilizer was stirred with $2 \mathrm{ml}$ gelatin medium melted at $37^{\circ} \mathrm{C}$ in a water bath (manipulation with samples at $37^{\circ} \mathrm{C}$ did not exceed $30 \mathrm{~s}$ ).

The tubes were taken out of the bath and gelatin with protoplasts was spread into a thin coat on the inside walls of the tubes using sterile glass rods. The protoplasts were cultivated at $23^{\circ} \mathrm{C}$ (Gabriel et al., 1992).

Isolation of regenerating and regenerated protoplasts from gelatin. The regeneration medium $(5 \mathrm{ml})$, enriched with $0.8 \mathrm{M}$ mannitol and $5 \mathrm{ml} 0.6 \mathrm{M} \mathrm{KCl}, \mathrm{pH} 5.5$, warmed to $37^{\circ} \mathrm{C}$, was added to the tubes with protoplasts embedded in gelatin. Gentle stirring helped to dissolve the gelatin in 2-5 min. Protoplasts were purified by centrifugation in regeneration medium with mannitol and $\mathrm{KCl}$ for $6 \mathrm{~min}$ at $670 \mathrm{~g}$. Washing with liquid regeneration YEPD-N1 $(1: 1)$ medium containing $0.8 \mathrm{M}$ mannitol was repeated two to three times (Gabriel et al., 1992).

Fixation of specimens. Cells in YEPD medium, fresh protoplasts in osmotic stabilizer, and regenerating protoplasts and revertants in liquid regeneration medium were fixed with $5 \%$ $(\mathrm{w} / \mathrm{v}) p$-formaldehyde in phosphate buffer at $\mathrm{pH} 6.9$, according to Pringle et al. (1989), supplemented with $20 \mathrm{mM} \mathrm{MgCl}_{2}$ and $10 \mathrm{mM}$ EGTA (Hašek et al., 1986). Fixation took place at room temperature for $90 \mathrm{~min}$. Before actin visualization, specimens were washed three times with phosphate buffer containing $\mathrm{MgCl}_{2}$ and EGTA without fixative at $\mathrm{pH} 6.9$.

Rhodamine phalloidin staining. Actin was labelled with rhodamine phalloidin R-415 (Molecular Probes) using the method of Pringle et al. (1989). A $100 \mu \mathrm{l}$ volume of cells in phosphate buffer, $\mathrm{pH} 6.9$, was stained with $10 \mu$ l of the original rhodamine phalloidin solution at $23^{\circ} \mathrm{C}$ in the dark. After staining for 30-60 min, with occasional shaking, the specimens were washed five times with phosphate-buffered saline and placed on grease-free slides. Dried slides were mounted in $p$-phenylenediamine in $90 \%(\mathrm{v} / \mathrm{v})$ glycerol, $\mathrm{pH} 9 \cdot 0$. All phases of staining were carried out in red light (Gabriel et al., 1992).

Phase-contrast and fluorescence microscopy. Cells, protoplasts and fixed specimens were examined by phase-contrast microscopy (Amplival, Zeiss Jena; magnification $\times 320$ ) and by 
fluorescence microscopy (Jenalumar, set filters: 4-,4-, G263, 570 ; primary magnification $\times 320$ ). For photography, Svema 19 DIN film was used at an exposure of $4 \mathrm{~min}$.

Nomarski differential interference contrast microscopy. This was done using the Jenalumar microscope at a magnification of $\times 320$ and an exposure of $1 \mathrm{~s}$.

\section{Electron microscopy}

(i) Freeze-etching. Replicas were prepared of protoplasts isolated from gelatin after $1-2 \mathrm{~h}, 5-6 \mathrm{~h}$ and $19-20 \mathrm{~h}$ of regeneration. A suspension of viable protoplasts in regeneration medium was frozen in Freon 22/liquid nitrogen and processed in a BA $360 \mathrm{M}$ Balzers apparatus (Moor \& Mühlethaler, 1963). Replicas were photographed in a Tesla BS 500 electron microscope.

(ii) Platinum-shadowed preparations. Protoplasts isolated after 1-2 h, 5-6 h and 19-20 h of regeneration in gelatin were washed with nutrient medium, pelleted, and $0.5 \%$ SDS was added. The protoplasts were allowed to stand for $5-10 \mathrm{~min}$ at $50^{\circ} \mathrm{C}$ (Kopecká \& Kreger, 1986). After three washes with distilled water, the specimens were placed on Formwar-coated grids, shadowed with platinum and photographed in a Tesla BS 500 electron microscope.

\section{RESULTS}

\section{Actin cytoskeleton in actin mutant cells and fresh protoplasts}

Cells of the actin mutant strain DBY 1693 with the act11 allele (Fig. 1a, b), in accordance with the findings of Novick \& Botstein (1985), formed faint cables that were difficult to record photographically, and bright actin patches on both the mother cell and the bud, at a permissive temperature of $23^{\circ} \mathrm{C}$. An accumulation of patches was often seen on the bud (Fig. 1b) and at the neck of the bud.

Protoplasts freshly prepared from an exponential culture of the actin mutant DBY 1693 strain grown at the permissive temperature (Fig. 1c) showed an even distribution of actin patches in the cortex (Fig. 1d). This was similar to that described previously in fresh protoplasts derived from the wild-type DBY 1690 strain with the $A C T 1$ allele (Gabriel et al., 1992).

\section{Actin cytoskeleton in protoplasts regenerating new cell walls}

The behaviour of the actin cytoskeleton during cell wall regeneration was analysed in protoplasts isolated from the regeneration medium after $1-2 \mathrm{~h}$ and $5-6 \mathrm{~h}$ of cultivation at $23^{\circ} \mathrm{C}$.

After 1-2 h, protoplasts increased in size but maintained their spherical shapes. The distribution of actin patches in the cortex was even (Fig. 1e, f). Isolated walls in electron micrographs showed incomplete regeneration of cell walls with distinct networks of glucan microfibrils (Fig. 2).

Protoplasts isolated at 5-6 h showed further increase in size but still retained spherical shapes (Fig. 1g). The actin patch distribution remained even (Fig. 1h) but no actin cables were observed. Electron micrographs showed regenerating cell walls with glucan microfibrils, now partially masked with amorphous matrix (Fig. 3).
In regenerating protoplasts of the actin mutant DBY 1693, act1-1, while new cell wall was being built, the even distribution of actin patches under the surface was identical to that reported by Gabriel et al. (1992) in the regenerating protoplasts of the wild-type strain DBY 1690 with the $A C T 1$ allele.

\section{Actin cytoskeleton in protoplasts with regenerated cell walls, reverting to budded cells}

This was studied using protoplasts isolated from two populations; one was incubated in the gelatin regeneration medium for $20 \mathrm{~h}$ and the other was grown for $15 \mathrm{~h}$ in a liquid regeneration medium after a $5 \mathrm{~h}$ cultivation in gelatin medium. The latter procedure was used to check that the isolation of protoplasts from the gelatin medium did not induce any changes in the actin cytoskeleton. The two populations, processed in the same way, gave similar results. Both were heterogenous cultures containing regenerating protoplasts (Fig. 1i, j), non-budding protoplasts with regenerated cell walls (Fig. $1 \mathrm{k}$, left), revertants showing various stages of bud (daughter cell) development (Fig. 1k, 1, m) and fully reverted daughter cells of the actin mutant (Fig. 1k, l).

Cells at all stages of intensive cell wall regeneration showed even distribution of actin patches (Fig. 1i). Shortly before bud emergence and during budding, actin patches delocalized to the growing bud and septum; some still remained on the initial protoplast with the regenerated cell wall (Fig. 1j, k, m).

In cells arising from reverted protoplasts, the distribution of actin corresponded to that found in the initial mutant cells.

The protoplasts from the two cultures observed by electron microscopy showed the presence of complete walls in both regenerated protoplasts (Fig. 4) and revertant cells (Fig. 5). Cross-fracture revealed that the walls were almost uniform in width (Fig. 6). In some of the regenerated protoplasts, an abundance of secretory vesicles and other components of the secretory pathway were detected (not shown).

The regenerated budding (reverting) protoplasts of act-1 actin mutant cells at the permissive temperature $\left(23^{\circ} \mathrm{C}\right)$ were characterized by: (1) the absence of cytoplasmic actin cables which, in wild-type reverting protoplasts run along the long axis of the budding protoplast (Gabriel et al., 1992); (2) the presence of scattered cortical actin patches which remained on both the protoplasts and mother cells during budding; and (3) heterogenous size (compare Fig. 1i with $\mathrm{k}$ or $\mathrm{m}$ ) similar to the appearance of the initial population of actin mutants grown at the permissive temperature (Fig. 1a).

\section{Finger-like invaginations in actin mutant cells and protoplasts}

Freeze-etching demonstrated the presence of finger-like invaginations on the protoplasmic fracture (PF) face of the plasma membrane in actin mutant cells (Fig. 7), 

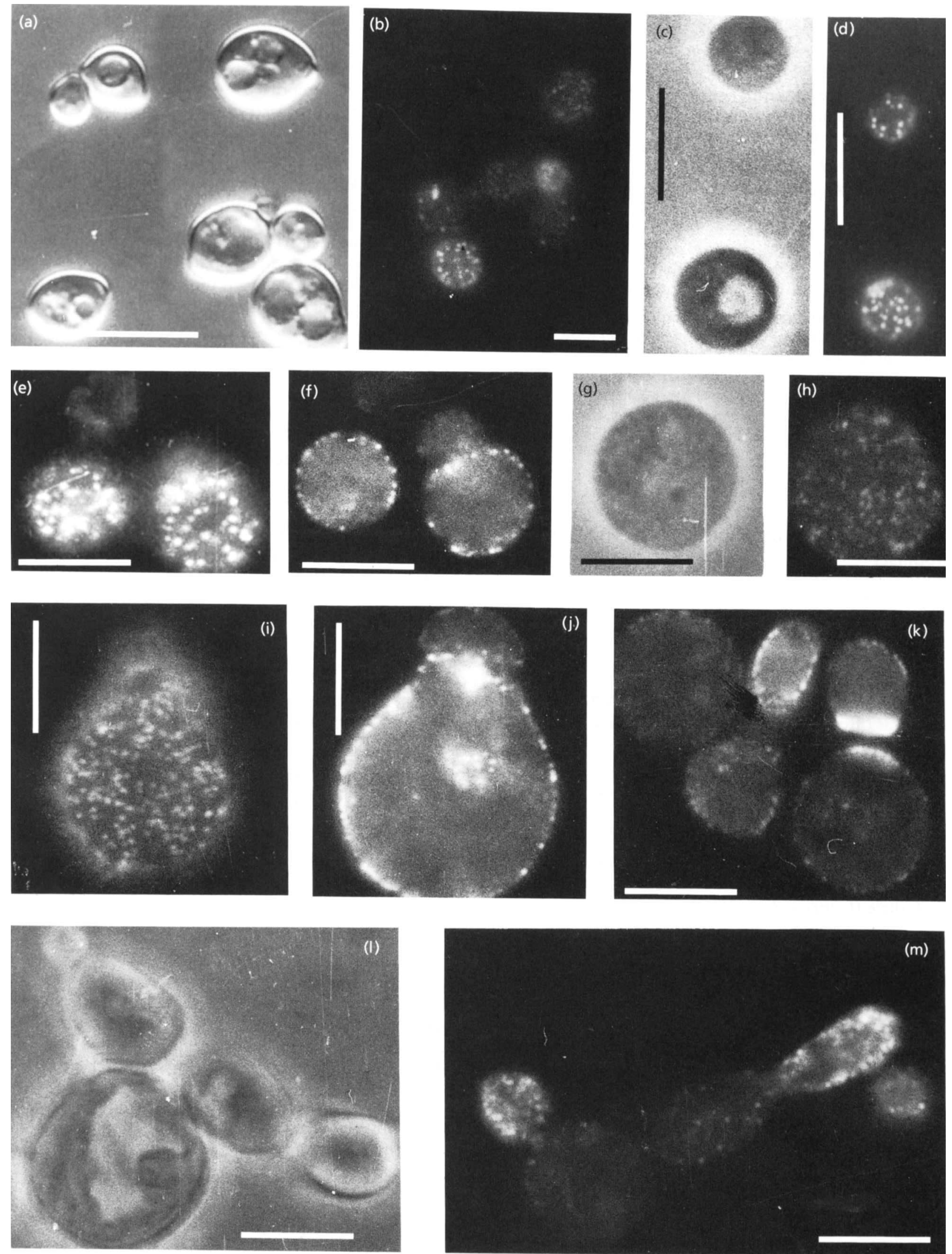

Fig. 1. For legend see facing page. 
protoplasts regenerating their walls (Fig. 8) and revertant cells (Fig. 6). Corresponding finger-like protrusions were identified on the exoplasmic fracture face of the plasma membrane (Fig. 6, left).

In the initial mother cells, these structures were few in number and scattered, but they accumulated in the area of bud emergence (Fig. 7, arrow) or near the bud neck (not shown).

In protoplasts regenerating their walls, finger-like invaginations were evenly distributed all over the surface (Fig. 8, arrow). Protoplasts which had completed wall regeneration, showed the finger-like invaginations loosely scattered over the surface, as shown on the exoplasmic fracture face (Fig. 6, left) and accumulated on the bud (Fig. 6, righthand arrow).

The finger-like invaginations seen on the protoplasmic fracture face appeared as conical or tubular structures, $50-100 \mathrm{~nm}$ in size, deeply sunken into the cortical cytoplasm. The corresponding structures could be identified as finger-like protrusions on the exoplasmic fracture face of the plasma membrane (Fig. 6, EF; see also insert in Fig. 7).

\section{DISCUSSION}

\section{Actin cytoskeleton in actin mutant cells}

Mother cells of the wild-type budding yeast $S$. cerevisiae DBY 1690 show actin cables arranged along the long axes of the cells while buds exhibit bright patches of actinstaining material localized near the cell surface. Wild-type cells are isogenic with actin mutant DBY 1693 cells except that they possess the non-mutated $A C T 1$ allele. Wildtype cells also have an actin ring in the form of a collar around the bud neck (Novick \& Botstein, 1985; Gabriel et al., 1992). This is a feature of wild-type budding yeasts first described by Kilmartin \& Adams (1984) and Adams \& Pringle (1984), and reviewed by Barnes et al. (1990) and Harold (1991).
Mutation in the actin gene has an effect on the assembly of actin in mutant cells. These cells have a weakened actin cytoskeleton and the actin pattern is altered. Even at the permissive temperature, act $1-1$ cells produce only fine cables, which are difficult to detect photographically, and bright patches present on the mother cell and bud. An accumulation of patches is often seen on the bud and its neck. The failure of the act1-1 cells to form clearly visible actin cables suggests either a defect in G-actin polymerization or formation of bundles of F-actin microfilaments (Novick \& Botstein, 1985).

The results of this work confirm the findings of Novick \& Botstein (1985) concerning faint actin cables in the act1-1 mutant cells, the presence of patches in the cortex of mutant mother cells and the concentration of actin patches on buds and their necks in these cells.

\section{The absence of actin cables in spherical yeast cells and protoplasts}

Novick \& Botstein (1985) were the first to report the complete disappearance of actin cables and rounding of cells in the actin mutant DBY 1963, act1-1, after cultivation at the restrictive temperature for $30 \mathrm{~min}$. The same finding was made in those mutant cells which were able to survive at $37^{\circ} \mathrm{C}$ for $24 \mathrm{~h}$ and grow isodiametrically (Kopecká \& Gabriel, 1990; Gabriel \& Kopecká, 1995).

Actin cables were not detected in some other types of actin mutants under restrictive conditions (Novick \& Botstein, 1985; Drubin et al., 1993) nor in cells with a mutation in 'bud site assembly genes' (cf. Drubin, 1991), such as CDC24, CDC42, CDC43 (Adams et al., 1990), BEM1 (Chenevert et al., 1992) and BUD/BEM1 (Chant $e t$ al., 1991). Actin cables were also missing in cells mutated in genes encoding actin-associated proteins, e.g. capping protein (Amatruda et al., 1990), profiline (Haarer et al., 1990), tropomyosin (Liu \& Bretscher, 1989), actin-

\footnotetext{
Fig. 1. Localization of actin in cells and freshly prepared protoplasts of ts conditionally lethal actin mutant, DBY 1693 (act1-1/act1-1), at various stages of growth and regeneration. Unless otherwise stated, regeneration was in gelatin regeneration medium at $23^{\circ} \mathrm{C}$. For fluorescence microscopy, cells or protoplasts were isolated, fixed and stained with rhodamine phalloidin. In all cases primary magnification was $\times 320$. Bars, $10 \mu \mathrm{m}$. (a) Nomarski differential interference contrast micrograph of cells in exponential growth at $23^{\circ} \mathrm{C}$. Cells reproducing by budding and celis without buds can be seen. (b) Fluorescence micrograph showing localization of actin cytoskeleton in exponential-phase cells at $23^{\circ} \mathrm{C}$. Actin cortical dots are accumulated in buds but are also present on mother cells. (c) Phase-contrast micrograph of protoplasts, freshly prepared using snail enzyme in osmotic stabilizer as described in Methods. (d) Fluorescence micrograph showing localization of actin cytoskeleton in freshly prepared protoplasts washed three times with osmotic stabilizer without snail enzyme. Cortical actin patches are detectable as evenly distributed structures at the protoplast cortex. (e, f) Fluorescence micrographs [upper (e) and middle (f) planes of focussing] showing localization of actin in protoplasts after regenerating new walls for $2 \mathrm{~h}$. Cortical actin patches are evenly distributed at the protoplast surface. (g) Phase-contrast micrograph of a protoplast regenerating for $5 \mathrm{~h}$. The protoplast is still spherical. (h) Fluorescence micrograph showing actin localization in a protoplast regenerating for $5 \mathrm{~h}$. Actin patches are evenly distributed in the protoplast cortex. (i, $j$ ) Fluorescence micrograph [upper (i) and middle (j) planes of focussing] showing actin localization in a protoplast regenerating for $19 \mathrm{~h}$. The upper plane (i) shows actin patches in a regenerating protoplast; actin patches appear to accumulate in two areas in the cortex of the protoplast (middle plane, j). (k) Fluorescence micrograph showing actin localization in protoplasts regenerating for $19 \mathrm{~h}$. A few actin patches are scattered at the cortex of a spherical regenerated protoplast (left). Accumulation of actin patches can be seen in the bud (central protoplast), and in the region of bud scar formation and at the base of the separating bud (right protoplast). (I) Phase-contrast micrograph of reverted protoplasts regenerating for $5 \mathrm{~h}$ in gelatin regeneration medium and then for $14 \mathrm{~h}$ in liquid medium at $23^{\circ} \mathrm{C}$. Three revertants are visible. (m) Fluorescence micrograph of reverting protoplasts, regenerating for $5 \mathrm{~h}$ in gelatin regeneration medium and then for $14 \mathrm{~h}$ in liquid medium at $23^{\circ} \mathrm{C}$. Actin patches partially disappeared in the original spherical regenerated protoplast and in the first generation revertant. Actin patches are, however, accumulated in the two buds.
} 

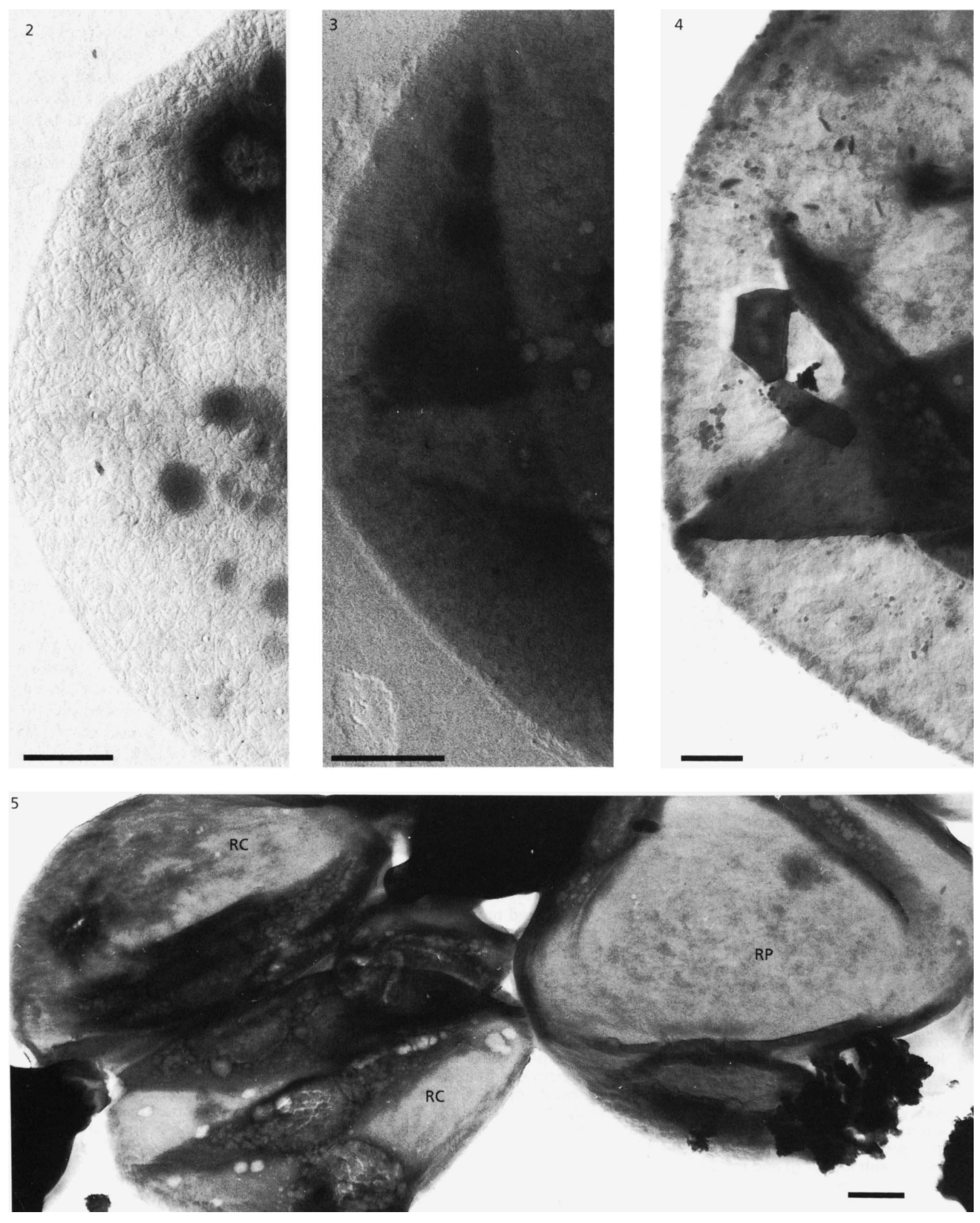

Figs 2, 3, 4 and 5. For legends see facing page. 
associated $67 \mathrm{kDa}$ (Adams et al., 1989) and $85 \mathrm{kDa}$ proteins (Drubin et al., 1988), and in the myosin MYO2 gene (Johnston et al., 1991). Furthermore, they were also absent in sec mutants (Svoboda \& Nečas, 1992). The disappearance of actin cables is manifested by a change in cell shape, i.e. cells become spherical, due to the loss of cell polarity.

Actin cables also disappear when the yeast cell is subjected to environmental stresses, such as centrifugation of the cell suspension, removal of glucose from the medium (Pringle et al., 1989) or the action of hypertonic solutions (Chowdhury et al., 1992). Protoplasting, the process of cell wall removal by enzymes in the presence of osmotic stabilizer, also results in disappearance of actin cables, as described by Gabriel et al. (1992) in S. cerevisiae, by Kobori et al. (1989) and Jochová et al. (1991) in Scbizosaccharomyces pombe, and in this paper in actin mutants of $S$. cerevisiae containing the act1-1 allele.

The finding of this identical phenomenon, i.e. disruption of actin cables, under a variety of environmental conditions may suggest that this is a non-specific response of the cell to a wide range of stresses, such as those involving temperature (in ts mutants), osmotic, metabolic and mechanical factors, or to a genetic change. The absence of actin cables interferes with cell polarity.

Our previous experiments demonstrated that the disappearance of actin filament cables affects the cell in the same way regardless of the inducing factor, i.e. mutation in the act1-1 gene (Gabriel \& Kopecká, 1995) or protoplasting in wild-type cells with the ACT1 allele (Gabriel et al., 1992). The consequences were identical: absence of actin cables produces loss of cell polarity, of transport of secretory vesicles to the bud, failure to reproduce by budding (Gabriel \& Kopecká, 1992a, b) and, eventually, isodiametrical growth (Gabriel \& Kopecká, 1995).

On the other hand, the disappearance of actin microfilaments and cables does not interfere with the synthesis of a new cell wall in regenerating protoplasts derived from wild-type $S$. cerevisiae containing the $A C T 1$ allele (Gabriel et al., 1992), Sch. pombe (Kobori et al., 1989) and from the actin mutant cells with the act $1-1$ allele. It can be concluded that the onset of cell wall synthesis does not depend on the presence of actin cables and can function without their direct involvement.

\section{Redistribution of actin patches during regeneration of cell walls in protoplasts of the actin mutant and during reversion of these protoplasts to cells}

Conversion of actin mutant cells grown at the permissive temperature $\left(23^{\circ} \mathrm{C}\right)$ to protoplasts resulted in an even distribution of actin patches all over the protoplast surface (Fig. 9). A similar pattern of actin patches has previously been observed in fresh protoplasts derived from the wildtype budding yeasts with the $A C T 1$ allele (Gabriel $e t$ al., 1992) and in protoplasts of the fission yeast $S c h$. pombe (Kobori et al., 1989; Jochová et al., 1991). This implies that this redistribution of actin patches is not a direct consequence of mutation in the actin gene.

The mechanism of this redistribution could be based on (1) lateral migration of actin patches attached to the inner face of the plasma membrane, (2) re-assembly of fragmented cytoplasmic actin microfilaments, or (3) a response of the cell to the loss of polarity due to the disruption of actin microfilaments caused by mutation in the actin gene and/or by the action of environmental stresses (osmotic shock or removal of the cell wall).

The even distribution of actin patches under the surface of protoplasts regenerating their cell walls, observed in wildtype as well as in actin mutant cells, gives support to the view that actin patches have a so far unidentified role in the construction of cell wall components. This concept in budding yeasts has been considered by Kilmartin \& Adams (1984), Adams \& Pringle (1984) and Novick \& Botstein (1985), and in the fission yeast Sch. pombe by Kobori et al. (1989) and Jochová et al. (1991).

The relationship of actin patches to growth regions of the cell surface is evident also in the cells to which the protoplasts with regenerated walls have reverted. Asymmetric redistribution of actin patches to the regions of intensive wall synthesis was seen in both actin mutant and wild-type cells (where, in addition, actin cables re-appeared; Gabriel et al., 1992).

It was of interest to find a certain number of actin patches persisting at the surfaces of mother cells of the actin mutant but not of the wild-type cells and, similarly, at the

Fig. 2. Electron micrograph of the $\beta-(1 \rightarrow 3)$-D-glucan fibrillar network formed by a DBY 1693 (act1-1/act1-1) protoplast after $2 \mathrm{~h}$ regeneration in gelatin regeneration medium at $23^{\circ} \mathrm{C}$. The protoplast was isolated from the gelatin, washed with lauryl sulphate and distilled water, and metal-shadowed. Bar, $1 \mu \mathrm{m}$.

Fig. 3. Electron micrograph of a regenerating cell wall of a DBY 1693 (act1-1/act1-1) protoplast after $5 \mathrm{~h}$ regeneration in gelatin regeneration medium at $23^{\circ} \mathrm{C}$. The fibrillar skeleton is partially masked by amorphous wall matrix. Prepared as described in legend to Fig. 2. Bar, $1 \mu \mathrm{m}$.

Fig. 4. Electron micrograph of a completely regenerated cell wall of a DBY 1693 (act1-1/act1-1) protoplast after 19 $\mathrm{h}$ regeneration in gelatin regeneration medium at $23^{\circ} \mathrm{C}$. The fibrillar skeleton is partially masked by amorphous wall matrix. Prepared as described in legend to Fig. 2. Bar, $1 \mu \mathrm{m}$.

Fig. 5. Electron micrograph of cell walls of a reverted protoplast with completely regenerated cell walls. RP, original protoplast with regenerated wall; RC, reverting cells. Protoplasts were regenerated for $5 \mathrm{~h}$ in gelatin regeneration medium and then for $14 \mathrm{~h}$ in liquid medium at $23^{\circ} \mathrm{C}$ and prepared as described in legend to Fig. 2. Bar, $1 \mu \mathrm{m}$. 

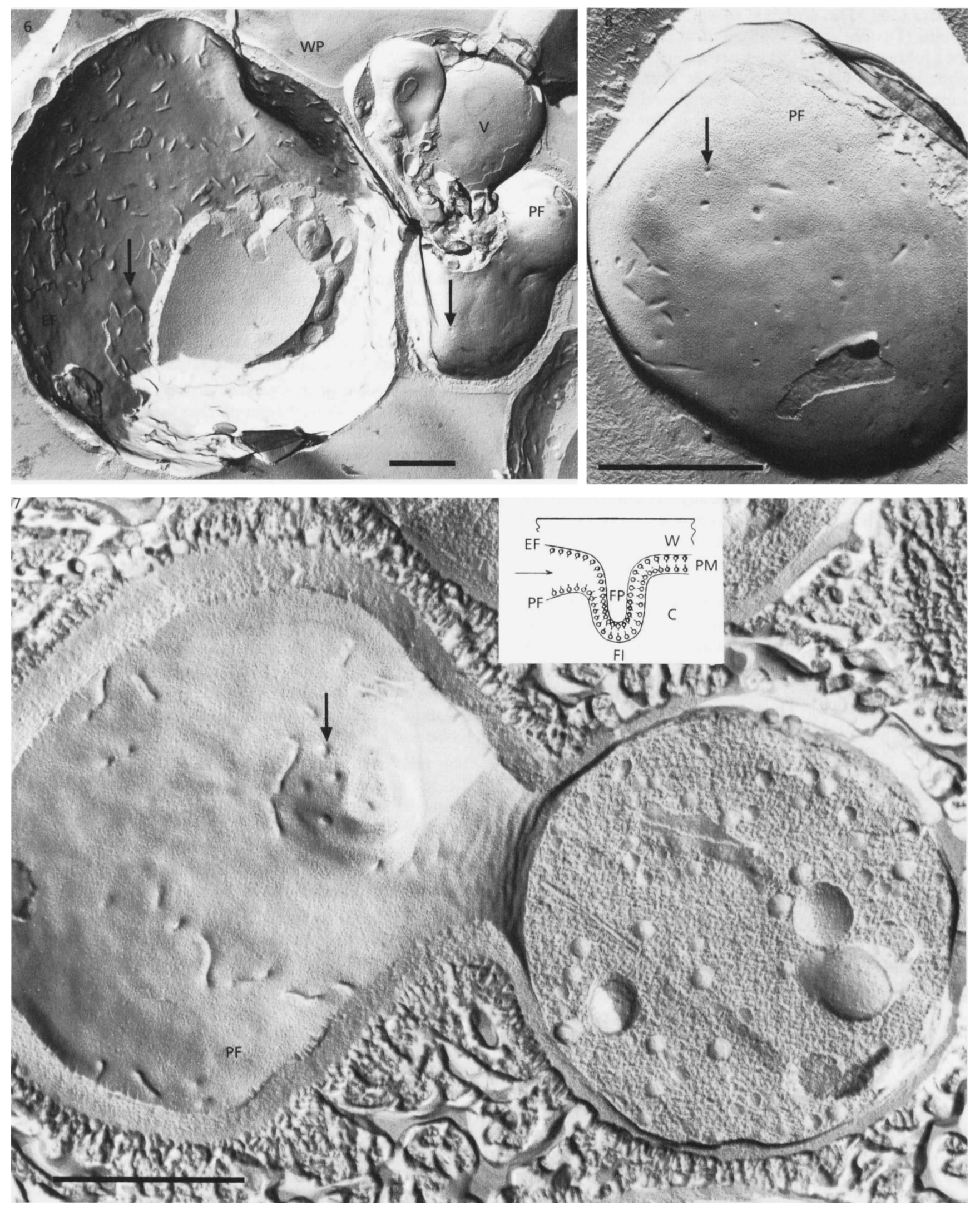

Figs 6, 7 and 8. For legends see facing page. 


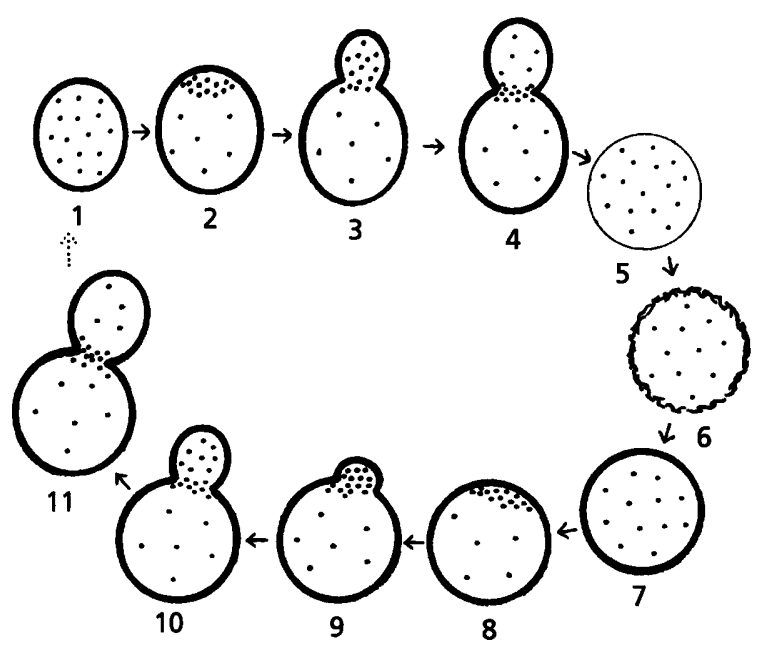

Fig. 9. Cortical actin patch distribution in actin mutant cells at the permissive temperature. Stages $1-4$, normal cell cycle: 1 , cell growing in size; 2 , accumulation of actin patches in the chitin ring and area of future budding; 3 , asymmetric distribution of actin patches accumulated in the bud; 4, septum formation with accumulated actin patches. Stages 5-11, protoplast formation: 5, even distribution of actin patches; 6, even distribution of actin patches during glucan fibril synthesis over the whole surface of the protoplast; 7 , assembly of amorphous matrix leading to complete regeneration of wall; 8 , complete restoration of the wall (exoskeleton) at the external surface of the plasma membrane and actin cytoskeleton at the inner surface of the plasma membrane enables asymmetric distribution and accumulation of actin patches in the area of the chitin ring and future bud; 9-11, budding of reverting protoplast; $10-11$, septum formation with the accumulation of actin patches. Cell division enables further reproduction by budding $(11 \rightarrow 1)$. Bold line, wall; thin line, plasma membrane; dots, actin patches.

surfaces of regenerated protoplasts derived from actin mutant cells but not of those prepared from wild-type cells. It is suggested that neither the walls of initial actin mutant mother cells nor the regenerated cells of their protoplasts have been completed because the transport of secretory vesicles probably occurs at a lower rate in the absence of actin cables. The presence of actin patches may be a sign of continuing synthesis of cell wall components. It would appear that changes in the pattern of actin patches are related to the 'activation' of cell (protoplast) surfaces during synthesis of wall components (Fig. 10). The continuing presence of actin patches is a result of mutation in the actin gene.

\section{Possible co-localization of actin patches and finger- like invaginations (cell wall protrusions)}

So far, actin patches have been associated mainly with areas of intensive cell wall synthesis (Barnes et al., 1990; Gabriel \& Kopecká, 1994). Some authors associate them with the distribution of chitin in the wall (Kilmartin \& Adams, 1984; Adams \& Pringle, 1984). This is in agreement with our findings of an increase in the number of actin patches in mother cells of the actin mutant DBY 1693 at the restrictive temperature (Gabriel \& Kopecká, 1995 ), in contrast to wild-type strain DBY 1690 . Novick \& Botstein (1985) relate this finding to the delocalization of chitin in the wall of the mother cell, unable to bud under restrictive conditions. Similar observations in the cdc24 mutant at the restrictive temperature were made by Sloat \& Pringle (1978), Sloat et al. (1981) and Hartland $e t$ al. (1993). All these findings indicate that the chitinglucan complex plays a stabilizing role in cell wall morphogenesis (Klis, 1994).

Apart from this view, which is based on staining chitin in cell walls with calcofluor - a reaction not necessarily specific for chitin (Streiblová, 1984; Pringle et al., 1989), a possible relationship of actin patches to the areas of synthesis of the main wall component, i.e. glucan, should also be considered. In relation to the synthesis of the three wall components of Saccharomyces, namely chitin, glucan and mannoprotein, both chitin synthases and glucan synthases are located at the plasma membrane, while synthesis of mannoproteins proceeds inside the cell (Farkaš et al., 1974; Fleet, 1991; Klis, 1994). De Nobel et

Fig. 6. Electron micrograph of a freeze-etched replica of a regenerated protoplast after $20 \mathrm{~h}$ cultivation at $23^{\circ} \mathrm{C}$. Fingerlike invaginations of plasma membrane have almost disappeared in the walled protoplast (WP), showing the exoplasmic fracture (EF) face of the plasma membrane with a few scattered finger-like invaginations (arrow). Many short invaginations typical for regenerated protoplasts can also be seen on the EF face, as described for wild-type yeast protoplasts by Nečas \& Svoboda (1976). In the reverting bud (V), finger-like invaginations are accumulated (arrow). Bar, $1 \mu \mathrm{m}$.

Fig. 7. Electron micrograph of a freeze-etched replica of an actin mutant cell grown to exponential phase at $23^{\circ} \mathrm{C}$, frozen, in nutrient medium, in Freon 22 and processed by the method of Moor \& Mühlethaler (1963). The micrograph shows a cross-fractured bud (right) containing many secretory vesicles. It also shows the cross-fractured wall of the mother cell with a large area of protoplasmic fracture (PF) in the plane of the plasma membrane and a small bud (arrow). Finger-like invaginations are scattered on the mother-cell surface, and are accumulated at the small bud. Bar, $1 \mu \mathrm{m}$. The insert explains the principal of freeze-etching nomenclature (Branton et al., 1975). The plasma membrane (PM) is fractured through the middle plane and the external fracture (EF) face remains joined to the wall (W), while the protoplasmic fracture (PF) face remains joined to the cytoplasm (C). FI, finger-like invagination of the plasma membrane; FP, finger-like protusion of the wall.

Fig. 8. Electron micrograph of a freeze-etched replica of an actin mutant protoplast regenerated for $1 \mathrm{~h}$ at $23^{\circ} \mathrm{C}$. Evenly distributed finger-like invaginations (arrow) can be seen in the protoplasmic fracture face of the plasma membrane. Bar, $1 \mu \mathrm{m}$. 


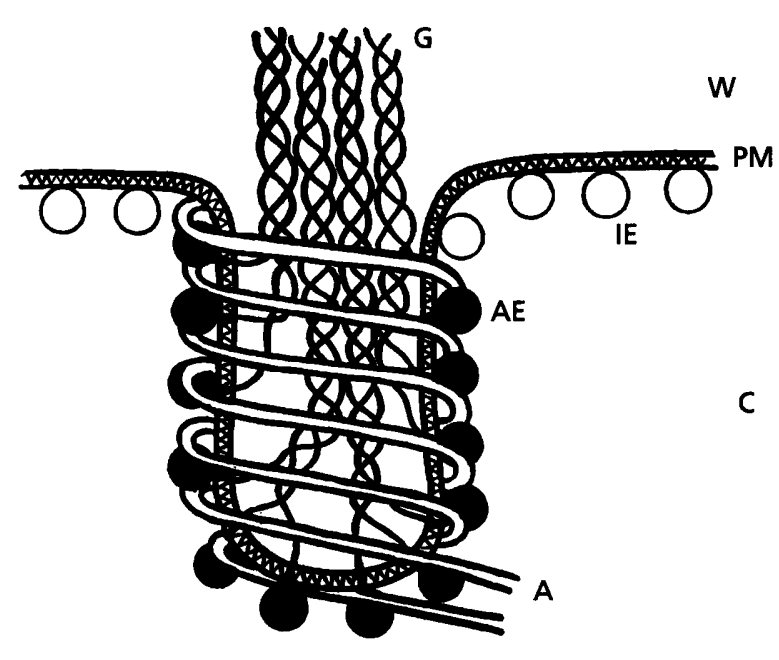

Fig. 10. Suggested role of cortical actin patch, based on the diagram of an actin microfilament (A) bound around a fingerlike invagination of the plasma membrane (PM) (Mulholland et al., 1994). IE, inactivated glucan synthase molecules at the PM; $A E$, glucan synthase activated by interaction with $A$. $A E$ synthesizes $\beta-(1 \rightarrow 3)$-D-glucan chains $(G)$ that grow into the finger-like invagination through the PM. Neighbouring glucan chains assemble into triple helices. Lateral assembly of triple helices leads to the formation of a $\beta$ - $(1 \rightarrow 3)$-D-glucan microfibril (Kopecká \& Gabriel, 1992) growing into the wall. Thus, actin patches in normal cells may be stabilized both by glucan fibrils in the extracellular area of the wall (W), and by actin microfilament cables (A) in the cytoplasm (C) bound around finger-like invaginations.

al. (1991), Roncero et al. (1988) and Shaw et al. (1991) have shown that chitin is present in the regions where the shape of the cell wall is completed, i.e. in the neck during budding and on the lateral wall of the mother cell, but is absent in the growing bud. In contrast to this, actin patches are largely located in the bud and its neck, but only occasionally in mother cells of the wild-type strain. Investigations of wall architecture of cells (Kopecká et al., 1974; Fleet, 1991; Kopecká, 1994) and protoplasts (Kreger \& Kopecká, 1976; Kopecká \& Kreger, 1986) have clearly shown that the essential structural component in de novo synthesis of cell walls in protoplasts, and most probably in the bud, are $\beta$-(1 $\rightarrow 3)$-D-glucan microfibrils. In addition, our findings of patterns of finger-like invaginations (cell wall protrusions) in cells and protoplasts studied by freeze-etching are strikingly similar to the pattern of actin patches during the cell cycle and during regeneration of yeast protoplasts. We believe that the finger-like structures detected by freeze-etching are identical with the finger-like invaginations of the plasma membrane described by Mulholland et al. (1994) who, using immunoelectron microscopic observations of ultrathin sections, demonstrated the relationship of these invaginations to the accumulation of cortical F-actin. We suggest that these finger-like invaginations may be the long-sought structure in the plasma membrane from which $\beta$ - $(1 \rightarrow 3)$-D-glucan microfibrils arise (Fig. 10) even though Mulholland et al. (1994) suggest their association with endocytosis.

\section{ACKNOWLEDGEMENTS}

The authors wish to thank Professor David Botstein and Dr Paola Grisafi, MIT, Cambridge, USA, for kindly providing ts conditionally lethal actin mutants of $S$. cerevisiae, Professor Herman J. Phaff, University of California, Davis, USA for a generous gift of phalloidin-rhodamine and Professor A. Svoboda for his kind interest, reading of the manuscript and useful comments, and for technical assistance Vladimíra Ramíková, Jiřina Drápalová, Jan Krobauer and Miloš Holubár. This work was supported by a grant from the Grant Agency of Czech Republic, no. 204/93/0667.

\section{REFERENCES}

Adams, A. E. M. \& Pringle, J. R. (1984). Relationship of actin and tubulin distribution to bud growth in wild-type and morphogenetic mutant Saccharomyces. J Cell Biol 98, 934-945.

Adams, A. E. M., Botstein, D. \& Drubin, G. (1989). A yeast-actinbinding protein is encoded by SAC 6, a gene found by suppression of an actin mutation. Science 243, 231-233.

Adams, A. E. M., Johnson, D. I., Longnecker, R. M., Sloat, B. F. \& Pringle, J. R. (1990). CDC42 and CDC43, two additional genes involved in budding and the establishment of cell polarity in the yeast Saccharomyces cerevisiae. J Cell Biol 111, 131-142.

Amatruda, J. F., Vannon, J. F., Tachell, K., Hug, C. H. \& Cooper, J. A. (1990). Disruption of the actin cytoskeleton in yeast capping protein mutants. Nature 344, 352-354.

Barnes, G., Drubin, D. C. \& Stearns, T. (1990). The cytoskeleton of Saccharomyces cerevisiae. Curr Opinion Cell Biol 2, 109-115.

Branton, D., Bullivant, S., Gilula, N. B., Karnovsky, M. J., Moor, H., Muhlethaler, K., Northcote, D. H., Packer, L., Satir, B., Satir, P., Speth, V., Staehelin, L. A., Steere, R. I. \& Weinstein, R. S. (1975). Freeze-etching nomenclature. Science 190, 54-56.

Chant, J., Corrado, K., Pringle, J. R. \& Herskowitz, I. (1991). Yeast BUD5, encoding a putative GDP-GTP exchange factor is necessary for bud site selection and interacts with bud formation gene BEM1. Cell 65, 1213-1224.

Chenevert, J., Corrado, K., Bender, A., Pringle, J. \& Herskowitz, I. (1992). A yeast gene (BEM1) necessary for cell polarization whose product contains two SH3 domains. Nature 356, 77-79.

Chowdhury, S., Smith, K. W. \& Guestin, M. C. (1992). Osmotic stress and the yeast cytoskeleton: phenotype-specific suppression of an actin mutation. $J$ Cell Biol 118, 561-571.

De Nobel, J. G., Klis, F. M., Ram, A., Van Unen, H., Priem, J., Munnik, T. \& Van Den Ende, H. (1991). Cyclic variations in the permeability of the cell wall of Saccharomyces cerevisiae. Yeast 7 , 589-598.

Drubin, D. (1991). Development of cell polarity in budding yeast. Cell 65, 1093-1096.

Drubin, D., Miller, K. G. \& Botstein, D. (1988). Yeast actin-binding proteins: evidence for a role in morphogenesis. J Cell Biol 107, 2551-2561.

Drubin, D. G., Heather, D. J. \& Vertmen, K. F. (1993). Actin structure and function: roles in mitochondrial organization and morphogenesis in budding yeast and identification of the phalloidin-binding site. Mol Biol Cell 4, 1277-1294.

Farkaš, V., Kovałłk, J., Košinová, A. \& Bauer, S. (1974). Autoradiographic study of mannan incorporation into the growing cell walls of Saccharomyces cerevisiae. J Bacteriol 117, 265-269.

Fleet, G. H. (1991). Cell walls. In The Yeast, vol. 4, pp. 199-279. Edited by A. H. Rose \& J. S. Harrison. London: Academic Press. 
Gabriel, M. \& Kopecká, M. (1992a). A single mutation in the actin gene can dissociate nuclear division from cytokinesis in the cell cycle of budding yeasts. Yeast 8, S 537.

Gabriel, M. \& Kopecká, M. (1992b). Morphogenesis of the cell wall in yeasts investigated in actin mutants and their protoplasts. In Sixth Cell Wall Meeting, Nijmegen, Book of Abstracts, p. 89. Edited by M. A. A. Sassen, J. M. M. Derksen, A. M. C. Emons \& A. M. C. Volters-Arts, The Netherlands: University of Nijmegen Press.

Gabriel, M. \& Kopecká, M. (1994). A role for actin patches in the synthesis of wall components. Cell Biol Int Rep 18, 561.

Gabriel, M. \& Kopecká, M. (1995). Disruption of the actin cytoskeleton in budding yeast results in formation of an aberrant cell wall. Microbiology 141, 891-899.

Gabriel, M., Kopecká, M. \& Svoboda, A. (1992). Structural rearrangement of the actin cytoskeleton in regenerating protoplasts of budding yeasts. J Gen Microbiol 138, 2229-2234.

Haarer, B. K., Lillie, S. H., Adams, A. E. M., Magdolen, V., Brandlow, W. \& Brown, S. S. (1990). Purification of profilin from Saccharomyces cerevisiae and analysis of profilin-deficient cells. J Cell Biol 110, 105-114.

Harold, F. M. (1991). Biochemical topology : from vectorial metabolism to morphogenesis. Bioscience Rep 11, 347-385.

Hartland, R. P., Vermuelen, C. A., Sietsma, J. H. \& Wessels, J. G. H. (1993). Cell wall assembly and morphogenesis in Saccharomyces cerevisiae. In Metabolic Compartmentation in Yeasts. Abstracts of the Sixteenth International Specialized Symposium on Yeasts (ISSY16), Arnhem, The Netherlands, pp. 176-177. Edited by W. A. Scheffers \& J. P. Van Dijken.

Hašek, J., Svobodová, J. \& Streiblová, E. (1986). Immunofluorescence of the miocrotubular skeleton in growing and drug-treated yeast protoplasts. Eur J Cell Biol 41, 150-156.

Jochová, J., Rupeš, I. \& Streiblová, E. (1991). F-actin contractile ring in protoplasts of the yeast Schizosaccharomyces. Cell Biol Int Rep 15, 607-610.

Johnston, G. C., Prendergast, J. A. \& Singer, B. A. (1991). The Saccharomyces cerevisiae MYO 2 gene encodes an essential myosin for vectorial transport of vesicles. J Cell Biol 113, 539-551.

Kelleti, T., Szabolzi, G., Lenvai, A. \& Garze, T. (1954). Untersuchungen über die lebensfähigen Eiweisskörper von Saccbaromyces cerevisiae. Die Regeneration in sterilen Filtrat von zertsorten Hefezellen. Acta Acad Sci Hung 5, 213-217.

Kilmartin, J. V. \& Adams, A. E. M. (1984). Structural rearrangement of tubulin and actin during the cell cycle of the yeast Saccbaromyces. J Cell Biol 98, 922-933.

Klis, F. M. (1994). Review: cell wall assembly in yeast. Yeast 10, 851-869.

Kobori, H., Yamada, N., Taki, A. \& Osumi, M. (1989). Actin is associated with the formation of the cell wall in reverting protoplasts of the fission yeast Schizosaccharomyces pombe. J Cell Sci 94, 635-646.

Kopecká, M. (1994). A study of the three-dimensional architecture of the cell wall and the molecular mechanisms of its assembly. Associate Professor Dissertation. Faculty of Medicine, Masaryk University, Brno, Czech Republic.

Kopecká, M. \& Gabriel, M. (1990). Some observations on morphology of temperature-sensitive yeast actin mutants. Zentralbl Mikrobiol 145, 336.

Kopecka, M. \& Gabriel, M. (1992). The influence of Congo red on the cell wall and $(1 \rightarrow 3)-\beta$-D-glucan microfibril biogenesis in Saccharomyces cerevisiae. Arch Microbiol 158, 115-126.
Kopecká, M. \& Kreger, D. R. (1986). Assembly of microfibrils in vivo and in vitro from $(1 \rightarrow 3)$ - $\beta$-D-glucan synthesized by protoplasts of Saccharomyces cerevisiae. Arch Microbiol 141, 387-395.

Kopecká, M., Phaff, H. J. \& Fleet, G. H. (1974). Demonstration of a fibrillar component in the cell wall of the yeast Saccharomyces cerevisiae and its chemical nature. J Cell Biol 62, 66-76.

Kreger, D. R. \& Kopecká, M. (1976). On the nature and formation of the fibrillar nets produced by protoplasts of Saccharomyces cerevisiae in liquid media: an electron microscopic, X-ray diffraction and chemical study. J Gen Microbiol 92, 207-221.

Liu, H. \& Bretscher, A. (1989). Disruption of the single tropomyosin gene in yeasts results in the disappearance of actin cables from the cytoskeleton. Cell 57, 233-242.

Moor, H. \& Muhlethaler, K. (1963). Fine structure in frozen-etched yeast cells. J Cell Biol 17, 609-628.

Mulholland, J., Preuss, D., Moon, A., Wong, A., Drubin, D. \& Botstein, D. (1994). Ultrastructure of the yeast actin cytoskeleton and its association with the plasma membrane. $J$ Cell Biol 125, 381-391.

Netas, O. (1961). Physical conditions as important factors for the regeneration of naked yeast protoplasts. Nature 192, 580-581.

Neťas, O. \& Svoboda, A. (1976). Regeneration of yeast protoplasts. A freeze-etching study. Z Allg Mikrobiol 16, 615-625.

Nečas, O. \& Svoboda, A. (1985). Cell wall regeneration and protoplast reversion. In Fungal Protoplasts, pp. 115-133. Edited by J. F. Peberdy \& L. Ferenczy. New York: Marcel Dekker.

Novick, P. \& Botstein, D. (1985). Phenotypic analysis of temperature-sensitive yeast actin mutants. Cell 40, 405-406.

Pringle, J. R., Preston, R. A., Adams, A. E. M., Stearns, T., Drubin, D. G., Haarer, B. K. \& Jones, W. E. (1989). Fluorescence microscopy methods for yeasts. Methods Cell Biol 31, 357-435.

Roncero, C., Valdivieso, M. H., Ribas, J. C. \& Duran, A. (1988). Isolation and characterization of Saccbaromyces cerevisiae mutants resistant to calcofluor white. J Bacteriol 170, 1950-1954.

Shaw, J. A., Mol, P. C., Bowers, B., Silverman, S. J., Valdivieso, M. H., Duran, A. \& Cabib, E. (1991). The function of chitin synthase-2 and synthase- 3 in the Saccharomyces cerevisiae cell cycle. J Cell Biol 114, 111-123.

Shortle, D., Novick, P. \& Botstein, D. (1984). Construction and genetic characterization of temperature-sensitive alleles of the yeast actin gene. Proc Natl Acad Sci US A 81, 4889-4893.

Sloat, B. F. \& Pringle, J. R. (1978). A mutant of yeast defective in cellular morphogenesis. Science 200, 1171-1173.

Sloat, B. F., Adams, A. \& Pringle, J. R. (1981). Roles of the CDC24 gene product in cellular morphogenesis during the Saccharomyces cerevisiae cell cycle. J Cell Biol 89, 395-405.

Streiblová, E. (1984). The yeast cell wall. A marker system for cell cycle controls. In The Microbial Cell Cycle, pp. 117-142. Edited by P. Nurse \& E. Streiblová. Boca Raton, Florida: CRC Press.

Svoboda, A. \& Nečas, O. (1966). Regeneration of yeast protoplasts prepared by snail enzymes. Nature 210, 845 .

Svoboda, A. \& Nečas, O. (1992). Cell wall formation in protoplasts of yeast secretory mutants. In Sixth Cell Wall Meeting, Nijmegen, Book of Abstracts, p. 204. Edited by M. A. A. Sassen, J. M. M. Derksen, A. M. C. Emons \& A. M. C. Volters-Arts. The Netherlands: University of Nijmegen Press.

Received 19 August 1994, revised 29 January 1995, accepted 15 February 1995. 